\title{
Kelekatan Orang Tua dan Kecerdasan Sosial pada Remaja Pondok Pesantren Modern
}

\section{Attachment of Parents and Social Intelligence among Adolescents of Modern Islamic Boarding School}

\author{
Nurjanah, Adi Heryadi \\ STIPSI Yogyakarta, Unjani Yogyakarta \\ Email: adiheryadi16@gmail.com
}

\begin{abstract}
KATA KUNCI Kelekatan Orang Tua, Remaja, Kecerdasan Sosial.
KEYWORDS Attachment of Parents, Adolescents, Social Intelligence.
\end{abstract}

ABSTRAK Penelitian ini bertujuan untuk mengetahui hubungan antara kelekatan orang tua dengan kecerdasan sosial remaja pondok pesantren modern. Kecerdasan sosial menjadi hal yang sangat penting karena pada dasarnya manusia tidak bisa hidup sendiri. Banyak aktivitas dalam kehidupan individu terkait dengan orang lain. Banyaknya fenomena sosial yang terjadi menggambarkan semakin mengikisnya kecerdasan sosial di masyarakat. Melemahnya rasa kepedulian sosial dan empati juga terjadi di kalangan remaja. Penelitian ini merupakan penelitian kuantitatif dengan teknik korelasi. Subjek penelitian adalah siswa Pondok Pesantren Modern Miftahunnajah dengan kriteria remaja berusia 10-22 tahun yang berjumlah 112 siswa. Teknik pengambilan sampel dalam penelitian ini menggunakan simple random sampling. Pengumpulan data menggunakan skala yang telah diuji validitas dan reliabilitasnya. Skala kelekatan orang tua dalam penelitian ini didasarkan pada tiga aspek kelekatan, yaitu kepercayaan, komunikasi dan keterasingan, yang berjumlah 41 item. Skala kecerdasan sosial dalam penelitian ini didasarkan pada dua aspek kecerdasan sosial, yaitu kesadaran sosial dan fasilitas sosial yang berjumlah 30 item. Dari uji hipotesis, diketahui bahwa koefisien korelasi (korelasi Pearson) adalah 0,376 dan tingkat signifikansi 0,000. Tingkat signifikansi lebih kecil dari 0,05 ( $\mathrm{p}<0,05)$ sehingga dapat dikatakan ada hubungan yang signifikan antara kelekatan orang tua dan kecerdasan sosial. Koefisien determinasi pada kedua variabel menunjukkan $\mathrm{R}$ square sebesar 0,121 atau sama dengan $12,1 \%$. Nilai ini menunjukkan kontribusi efektif kelekatan orangtua yang berkontribusi terhadap kecerdasan sosial adalah sebesar $12,1 \%$ dan $87,9 \%$ dipengaruhi oleh faktor lain. 
This study aims to determine the relationship between the attachment of parents to the social intelligence of adolescent Miftahunnajah Modern Islamic Boarding School. Social intelligence becomes a very important thing because basically humans cannot live alone. Many activities in an individual's life are related to others. The many social phenomena that occur illustrate the increasingly reduced social intelligence in society. Weakening social sense and empathy also occur among adolescents. The research subject was students of the Modern Miftahunnajah Islamic Boarding School with the criteria of adolescents aged 10-22 years. The number of subjects in this study were 112 students. The sampling technique in this study used a simple random sampling. Data collection uses a scale that has been tested for validity and reliability. The scale of parental attachment in this study was based on three aspects of stickiness, namely trust, communication and alienation, which amounted to 41 items. The scale of social intelligence in this study is based on two aspects of social intelligence, namely social awareness and social facilities totaling 30 items. From the hypothesis test, it is known that the correlation coefficient (pearson correlation) is 0.376 and the significance level is 0.000. The significance level is smaller than 0.05 ( $p$ $<0.05)$ so that it can be said that there is a significant relationship between the attachment of parents and social intelligence. The coefficient of determination on the two variables shows $R$ square of 0.121 or equal to $12.1 \%$. This value shows the effective contribution of parental attachments that contribute to parental intelligence is equal to $12.1 \%$ and $87.9 \%$ social intelligence is influenced by other factors.

\section{PENDAHUUAN}

\begin{tabular}{lllr}
\multicolumn{4}{c}{ Manusia merupakan makhluk sosial } \\
yang selalu & berhubungan dan \\
membutuhkan & orang lain untuk \\
melangsungkan & kehidupan sehari-hari.
\end{tabular}
Sebagai manusia, dalam tingkah lakunya selalu berhubungan dengan lingkungan tempat dia tinggal. Hubungan dengan orang lain adalah bagian yang tidak pernah lepas dari kehidupan individu sehari-hari.

Berdasarkan penelitian Dewi dan Valentina (2013) menyatakan bahwa kecerdasan sosial pada remaja saat ini semakin rendah, hal tersebut dibuktikan dengan sebagian besar remaja saat ini hanya mementingkan diri sendiri, tidak ada tata krama, tidak saling menegur, tidak saling peduli antara satu dengan yang lainnya, serta kurangnya kemampuan untuk berinteraksi dengan teman-temannya.
Goleman (2015), mengemukakan juga bahwa kecerdasan sosial merupakan kemampuan seseorang untuk memahami orang lain dan bagaimana reaksi mereka terhadap berbagai situasi yang berbeda. Kecerdasan sosial membantu seorang siswa untuk berinteraksi dengan teman sebaya dan dapat berpengaruh pada prestasi akademik.

Masa perkembangan remaja yang paling sulit adalah berhubungan dengan kecerdasan sosial. Untuk mencapai tujuan dari pola sosialisasi yang baik, remaja memerlukan berbagai penyesuaian baru, yaitu penyesuaian diri dengan kelompok sebaya, perubahan dalam perilaku sosial, pengelompokan sosial baru, nilai-nilai baru dalam persahabatan, nilai-nilai baru dalam dukungan, penolakan sosial mau pun nilai- 
nilai baru dalam berbagai lingkungan yang dihadapinya.

Pondok Pesantren Modern

Miftahunnajah adalah salah satu pondok pesantren yang beroperasi dalam bidang pendidikan dan keagamaan. Usia santri dalam pondok tersebut adalah usia 10-22 tahun yang pendidikan SMP nya berada dalam satu yayasan dan siswa merupakan santri pondok pesantren.

Dengan keharusan santri untuk tinggal di pondok pesantren, menuntut setiap santri untuk memiliki kecerdasan sosial tinggi. Karena mereka diharuskan berinteraksi dengan lingkungan pondok selama masa studi yang cukup lama. Individu yang kurang memiliki kecerdasan sosial akan terhambat dalam banyak hal terutama dalam keikutsertaan segala aktivitas yang berada di lingkungan pondok maupun sekolah.

Banyak hal yang mempengaruhi kecerdasan sosial. Salah satunya yaitu kelekatan. Kelekatan ialah sebuah proses berkembangnya ikatan emosional secara resiprokal (timbal balik) antara bayi/anak dan pengasuh (orangtua). Kelekatan yang baik dan sehat dialami seorang bayi yang menerima kasih sayang yang stabil dari kehadiran orangtua yang konsisten, sehingga bayi atau anak dapat merasakan sentuhan hangat, gerakan lembut, kontak mata yang penuh kasih dan senyuman orangtua (Adriani \& Wirjadmadi, 2016).

Taylor, Peplau, dan Sears (2009) mengungkapkan bahwa kelekatan adalah ikatan emosional yang kuat dengan orang lain yang signifikan, bayi merespon secara positif kepada orang tertentu, merasa lebih baik ketika dekat dengan mereka, dan mencari mereka saat ketakutan.
Kelekatan terhadap orangtua pada masa remaja dapat membantu mengembangkan kompetensi sosial dan kesejahteraan sosial remaja (Santrock, 2007), yang terlihat dari tingginya harga diri, penyesuaian emosional, dan kesehatan fisik (Desmita, 2012).

Individu yang memiliki kelekatan yang aman (secure attachment) akan menunjukkan bermacam-macam karakteristik positif, seperti menjadi lebih pintar dalam menyelesaikan masalah dan lebih memiliki kompetensi sosial, seperti lebih kooperatif, patuh pada orangtua dan memiliki hubungan yang lebih baik dengan teman sebayanya (Retnaningsih, dalam Benyamin, 2010). Individu yang memiliki kompetensi sosial yang tinggi memiliki hubungan yang kuat dengan orangtua mereka, tidak merasa diasingkan dan mengalami konflik yang sedikit dengan orangtua. Begitu juga mereka cenderung memiliki kualitas persahabatan yang lebih baik, merasa bahwa teman-teman mereka akan memberikan dukungan emosional dan material dan mereka merasa tidak diasingkan dari teman-teman (Smart \& Sanson, dalam Benyamin, 2010).

Usia santri yang rata-rata siswa SMP adalah 12 hingga 15 tahun yang menurut Hurlock (2013) adalah masa pencarian identitas diri, siapa dirinya, apa perannya di masyarakat. Selain itu pada masa remaja pengaruh teman sebaya begitu kuat mempengaruhi remaja sehingga dibutuhkan lingkungan yang kondusif untuk mendukung tumbuh kembangnya. Alur pemikiran yang dibangun oleh peneliti seperti tergambar pada gambar berikut ini: 


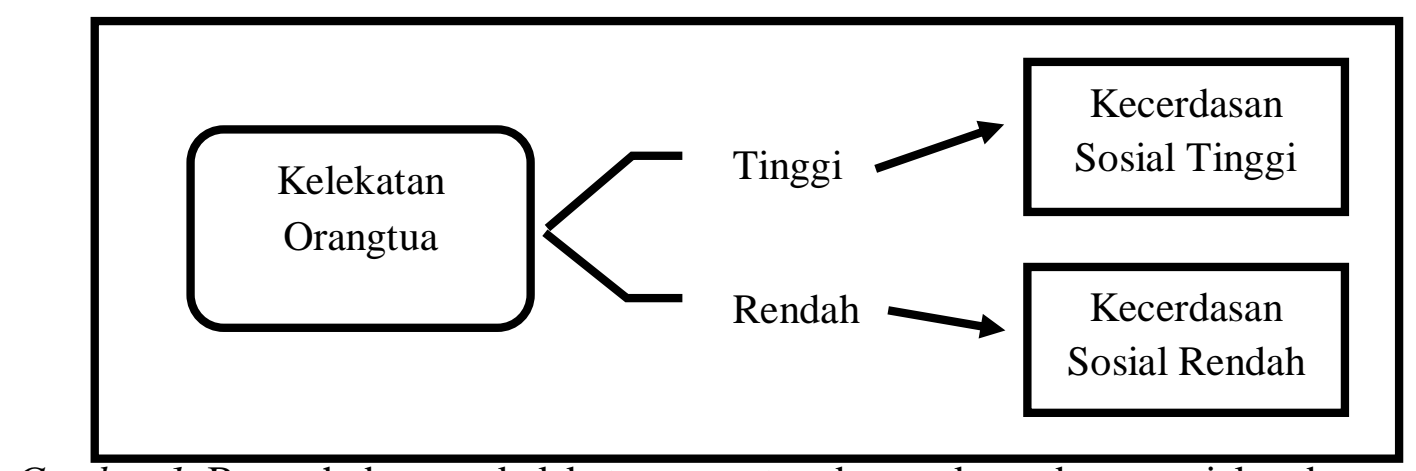

Gambar 1. Bagan hubungan kelekatan orangtua dengan kecerdasan sosial pada remaja Pondok Pesantren Modern Miftahunnajah.

\section{METODE PENELITIAN Pendekatan}

Penelitian ini merupakan penelitian kuantitatif dengan teknik korelasi.

\section{Partisipan}

Populasi dalam penelitian ini adalah seluruh santri Pondok Pesantren Modern Miftahunnajah dengan subjek penelitian remaja usia 10-22 tahun sebanyak 112 santri. Penelitian ini menggunakan teknik random sampling.

\section{Instrumen}

Instrumen pengumpulan data dalam penelitian ini menggunakan skala kelekatan orangtua (41 item, $\alpha=0,928$ ) yang disusun berdasarkan aspek kelekatan orangtua menurut Armsden dan Greenberg (2009) yaitu:

1. Kepercayaan (trust)

Rasa percaya diukur berdasarkan sejauh mana remaja memandang merasa orangtua akan selalu ada, merasa bergantung dengan orangtua, mempercayai orangtua, dan mendapatkan rasa aman dari orangtua.

2. Komunikasi diukur berdasarkan sejauh mana remaja memiliki sikap merasa dekat dengan orangtua, merasa dicintai orangtua, merasa dihargai orangtua, merasa diterima, dan terbuka dengan orangtua.

3. Alienasi diukur berdasarkan sejauh mana remaja mengalami perasaan negatif seperti marah, sedih atau kecewa dengan orangtua. Perasaan negatif berkaitan dengan adanya perasaan dihindari oleh orangtua, merasa diabaikan oleh orangtua, merasa ditolak oleh orangtua.

Sementara skala kecerdasan sosial (30 item, $\alpha=0,899$ ) disusun berdasarkan aspek kecerdasan sosial menurut Goleman (2015), yaitu aspek kesadaran sosial dan kecakapan sosial.

\section{Kesadaran Sosial}

Kesadaran sosial mengarah pada sebuah spectrum dan yang secara tidak langsung merasakan apa yang dirasakan oleh orang lain, memahami perasaan dan pikiran nya untuk ikut terlibat dalam situasi yang sulit. Kesadaran sosial ini meliputi:

a. Primal empathy (empati terpenting); perasaan terhadap seseorang yang lain, merasakan tanda isyarat emosi.

b. Attuntment (penyesuaian atau adaptasi); mendengarkan dengan kemauan penuh, membiasakan diri mendengarkan seseorang.

c. Empathic accuracy (empati yang tepat); memahami pikiran gagasan, perasaan dan kehendak orang lain.

d. Social cognition (kesadaran sosial); mengetahui bagaimana kehidupan bersosialisasi terjadi. 
2. Kecakapan Sosial

Sementara kecakapan sosial secara sederhana yakni merasakan perasaan orang lain, atau sekedar tahu apa yang mereka pikirkan ataupun inginkan, tidak sama sekali menjamin sebuah keberhasilan dalam suatu interaksi. Kecakapan sosial terbentuk dalam kesadaran sosial untuk memenuhi sebuah interaksi yang lancar dan efektif. Spektrum kecakapan sosial meliputi:
a. Synchrony (Sinkroni) : Menginteraksikan dengan lancar pada level non verbal.
b. Self Presentation (Presentasi Diri Pribadi) : Mempresentasikan diri sendiri dengan efektif.
c. Influence Menghadirkan jalan keluar dari interaksi sosial.

d. Concern (Peduli) : Peduli terhadap orang lain sesuai dengan kebutuhan dan perilaku masing-masing individu skala kecerdasan sosial akan menunjukkan tinggi atau rendahnya kecerdasan sosial.

\section{Teknik Analisis Data}

Data penelitian ini dianalisis dengan menggunakan analisis korelasi Pearson.

\section{ANALISIS DAN HASIL}

Hasil analisis data menunjukkan koefisien korelasi (Pearson correlation) sebesar 0,348 dan taraf signifikansi 0,000. Taraf signifikansi lebih kecil dari 0,05 $(p<0,05)$ sehingga dapat dikatakan bahwa terdapat hubungan yang signifikan antara kelekatan orangtua dengan kecerdasan sosial seperti terlihat pada tabel di bawah ini :

Tabel 1

Korelasi

\begin{tabular}{|c|c|c|c|}
\hline & & $\begin{array}{c}\text { Kelekatan } \\
\text { Orang } \\
\text { Tua } \\
\end{array}$ & Kecerdasan Sosial \\
\hline \multirow{3}{*}{$\begin{array}{l}\text { Kelekatan } \\
\text { Orangtua }\end{array}$} & $\begin{array}{l}\text { Pearson } \\
\text { Correlation }\end{array}$ & 1 & $.348^{* * *}$ \\
\hline & Sig. (2-tailed) & & .000 \\
\hline & $\mathrm{N}$ & 112 & 112 \\
\hline \multirow{3}{*}{$\begin{array}{l}\text { Kecerdasan } \\
\text { Sosial }\end{array}$} & $\begin{array}{l}\text { Pearson } \\
\text { Correlation }\end{array}$ & $.348^{* *}$ & 1 \\
\hline & Sig. (2-tailed) & .000 & \\
\hline & $\mathrm{N}$ & 112 & 112 \\
\hline
\end{tabular}


Tanda positif pada koefisien korelasi menunjukkan bahwa arah hubungan kedua variabel tersebut adalah positif. Artinya, semakin tinggi kelekatan orangtua maka semakin tinggi pula kecerdasan sosial pada santri Pondok Pesantren Modern Miftahunnajah. Sebaliknya, semakin rendah kelekatan orangtua maka semakin rendah pula kecerdasan sosial pada santri Pondok Pesantren Modern Miftahunnajah. Koefisien determinasi pada kedua variabel tersebut menunjukkkan $\mathrm{R}$ square sebesar 0,121 atau sebesar $12,1 \%$. Nilai tersebut menunjukkan sumbangan efektif kelekatan orangtua yang berkontribusi terhadap kecerdasan orangtua adalah sebesar $12,1 \%$ dan $87,9 \%$ kecerdasan sosial dipengaruhi oleh faktor lain.

\section{DISKUSI}

Berdasar hasil analisa di atas, maka hasil tersebut dapat menjawab pertanyaan penelitian, yaitu ada hubungan antara kelekatan orangtua dengan kecerdasan sosial remaja Pondok Pesantren Modern Miftahunnajah. Dari hasil analisa statistik menunjukkan koefisien korelasi (pearson correlation) sebesar 0,348 dan taraf signifikansi 0,000. Taraf signifikansi lebih kecil dari $0,05(\mathrm{p}<0,05)$ sehingga dapat dikatakan bahwa terdapat hubungan yang signifikan antara kelekatan orangtua dengan kecerdasan sosial, sehingga hipotesis dalam penelitian ini dinyatakan diterima.

Mengingat keaslian penelitian yang belum pernah ada penelitian yang menguji secara langsung hubungan antara kedua variabel yaitu kelekatan orangtua dengan kecerdasan sosial. Namun, adanya hubungan yang signifikan sejalan penelitian Rachmadtullah dan Wirasti (2017) yang menyatakan bahwa pola asuh orangtua memiliki hubungan yang positif dengan kecerdasan sosial. Artinya semakin baik pola asuh orangtua maka semakin baik kecerdasan sosial siswa. Sebaliknya, semakin buruk pola asuh orangtua maka semakin buruk pula kecerdasan sosial siswa.

Senada dengan penelitian yang dilakukan oleh Purnama dan Wahyuni (2017) pada SMPN 21 Pekanbaru dengan judul kelekatan orangtua pada ibu dan ayah dengan kompetensi sosial pada remaja menyatakan bahwa terdapat hubungan yang signifikan antara kelekatan pada ibu dan ayah dengan kompetensi sosial pada remaja. Artinya semakin tinggi kelekatan ayah dan ibu maka akan semakin tinggi kompetensi sosial remaja. Sebaliknya, jika semakin rendah kelekatan ayah dan ibu maka kompetensi sosial remaja akan semakin rendah.

Penelitian lain yang dilakukan oleh Febrianingsih (2016) menunjukkan bahwa gaya kelekatan orangtua mempengaruhi kompetensi sosial remaja. Penelitian ini menyatakan bahwa remaja dengan kelekatan aman memunculkan kompetensi sosial yang lebih tinggi dari gaya kelekatan lainnya. Gaya kelekatan aman akan membuat individu lebih kooperatif, empati, tanggungjawab, dan pengendalian diri yang lebih tinggi dari yang lainnya.

Terwase, Ibaishwa, dan Enemari (2016) mengungkapkan bahwa pola asuh orangtua dengan gaya permisif secara signifikan berpengaruh pada tingkat kecerdasan sosial remaja. Sebaliknya, pola asuh otoriter tidak meningkatkan kecerdasan sosial remaja. Sedangkan Groh, Fearon, Bakermans-Kranenburgs, Ijzendoorn, Steele, dan Roisman (2015) menyatakan bahwa kelekatan orangtua sejak bayi sangat mempengarui kehidupan sosial anak pada awal remaja. kelekatan aman akan membentuk kompetensi sosial yang bagus bagi individu.

\section{SIMPULAN}

Hasil penelitian ini menunjukkan terdapat hubungan positif dan signifikan antara kelekatan orangtua dengan kecerdasan sosial pada remaja Pondok Pesantren Modern Miftahunnajah. Sumbangan efektif kelekatan orangtua yang 
berkontribusi terhadap kecerdasan sosial adalah sebesar $12,1 \%$.

\section{SARAN}

Berdasarkan hasil analisis dan diskusi tentang hubungan kelekatan orangtua dengan kecerdasan sosial pada remaja Pondok Pesantren Modern Miftahunnajah, maka:

1. Ada hubungan positif dan signifikan antara kelekatan orangtua dengan kecerdasan sosial pada remaja Pondok Pesantren Modern Miftahunnajah, artinya kelekatan antara orang tua dan anak yang ditandai dengan terbangunnya komunikasi yang saling percaya dan orang tua yang selalu hadir disaat anak membutuhkan teman untuk berkomunikasi perlu menjadi perhatian dari orang tua.

2. Sumbangan efektif kelekatan orangtua yang berkontribusi terhadap kecerdasan sosial adalah sebesar 12,1\% dan $87,9 \%$ kecerdasan sosial dipengaruhi oleh faktor lain artinya variable kelekatan terbukti memberikan sumbangan pada pembentukan kecerdasan sosial remaja walau hanya $12,1 \%$. Orang tua dan remaja masa kini perlu berkomunikasi dan berdiskusi lebih banyak untuk memformat kembali pola kelekatan di era digital dimana komunikasi telah bisa dimediasi oleh teknologi.

3. Kelemahan dalam penelitian ini adalah peneliti tidak mengkategorisasikan sebelumnya antara subjek penelitian yang masih memiliki orang tua lengkap, orang tua tunggal bahkan sudah tidak memilki orang tua sehingga untuk peneliti selanjutnya yang tertarik dengan topik kelekatan orang tua agar lebih memperhatikan faktor di atas.

\section{DAFTAR PUSTAKA}

Adriani, M., \& Wirjadmadi, B. (2016).

Peranan gizi dalam siklus kehidupan. Jakarta: Prenadamedia Group.
Armsden, G. C., \& Greenberg, M.T. (2009). The inventory of parent and peer attachment: Individual differences and their relationship to psychological well-being in adolescence. Journal of Youth and Adolescence, 16(5), 427-454.

Benyamin. (2010). Memperkuat peran IPS dalam membelajarkan keterampilan sosial dan resolusi konflik: Pidato pengukuhan guru besar Universitas Pendidikan Indonesia.Diakses dari http://file.upi.edu/Direktori/PID ATO/3._PIDATO_PENGUKUH AN_BUNYAMIN.pdf.

Desmita. (2012). Psikologi perkembangan. Bandung: Remaja Rosda.

Dewi, A. A. A., \& Valentina, T.D. (2013). Hubungan kelekatan orang tuaremaja dengan kemandirian pada remaja di SMK N 1 Denpasar. Jurnal Psikologi Udayana, 1(1), 181-189.

Febrianingsih, F. P. (2016). Perbedaan kompetensi sosial remaja ditinjau dari gaya kelekatan dengan teman sebaya (Skripsi). Universitas Muhammadiyah Malang, Malang, Jawa Timur.

Goleman, D. (2015). Social intelligence:

Ilmu baru tentang hubungan antar manusia. Jakarta: Gramedia.

Groh, A.M., Fearon. R. P., BakermansKranenburgs, M. J., Ijzendoorn, M.H., Steele, R.D., \& Roisman, G. I. (2015). The significance of attachment security for children's social competence with peers : A meta-analytic study. Attachment and Human Development, 16(2), 103-136.

Hurlock, B. E. (2013). Psikologi perkembangan $\left(5^{\text {th }}\right.$ ed.). Jakarta: Erlangga.

Purnama, R.A., \& Wahyuni, S. (2017). Kelekatan (attachment) pada ibu dan ayah dengan kompetensi sosial pada remaja. Jurnal Psikologi Universitas Islam 
Negeri Sultan Syarif Kasim Riau, 13(1), 30-40.

Santrock, J.W. (2007). Remaja jilid $2\left(11^{\text {th }}\right.$ ed.). Jakarta: Erlangga.

Taylor, S.E., Peplau, L.A., \& Sears, D. (2009). Psikologi sosial. Jakarta: Prenada Media Group.

Terwase, J. M., Ibaishwa, R.L., \& Enemari, J. (2016). Parenting style as predictors of social intelligence among adolescents in idoma land. Mediterranean Journal of Social Sciences, 7(1), 181-187. 